\title{
EFFECT OF MAGNETRON TARGET TEMPERATURE ON DEPOSITION RATE AND STRUCTURE OF Zr-ZrO 2 THIN FILMS
}

\author{
J. Čyvienè, M. Laurikaitis, and J. Dudonis \\ Kaunas University of Technology, Studentu 50, LT-51368 Kaunas, Lithuania \\ E-mail: jurgita.cyviene@ktu.lt
}

Received 26 May 2004

Dedicated to the 100th anniversary of Professor K. Baršauskas

\begin{abstract}
The influence of temperature of zirconium target on the process of reactive magnetron sputtering has been investigated in this work. Two processes have been studied: when the magnetron $\mathrm{Zr}$ target was not cooled in a common way, but thermally isolated from the magnetron cathode ("hot" target), and when the magnetron $\mathrm{Zr}$ target was cooled with water flow ("cold" target). First, current-voltage characteristics of $\mathrm{Zr}$ metal target were measured for the two cases when oxygen partial pressure is constant, and dependences of magnetron cathode voltage on partial pressure of oxygen, when magnetron discharge current is constant. Dependences of the film deposition rate on partial pressure of oxygen have also been measured. After complete analysis of the influence of the target temperature on this process of reactive magnetron sputtering, $\mathrm{ZrO}_{2}$ thin films were deposited on $\mathrm{Si}(111)$ substrates. The structure of films was investigated by XRD.
\end{abstract}

Keywords: reactive magnetron sputtering, zirconia

PACS: 81.15.Cd

\section{Introduction}

Zirconium oxide $\left(\mathrm{ZrO}_{2}\right.$, zirconia) has three stable crystal structures: monoclinic $\left(<1170^{\circ} \mathrm{C}\right)$, tetragonal (between 1170 and $2370^{\circ} \mathrm{C}$ ), and cubic phases $\left(>2370^{\circ} \mathrm{C}\right)$. The cracking during the tetragonal-monoclinic phase transition can be depressed by decreasing grain size or adding a stabilizer, such as $\mathrm{Y}_{2} \mathrm{O}_{3}, \mathrm{CaO}$, $\mathrm{MgO}$ or $\mathrm{CeO}_{2}$ [1].

Zirconia films with heat resistance, low thermal conductivity, a relatively high dielectric constant, high refractive index, high transparency in the visible and near-infrared region [2], extreme chemical inertness, and a high laser damage threshold have been used in a variety of applications, such as thermal barrier coatings [3], optical filters, laser mirrors, alternative gate dielectrics in microelectronics [4], a buffer layer for a high- $T_{\mathrm{c}}$ ceramic superconductor on $\mathrm{Si}$. The stabilized cubic zirconia is a good oxygen conductor and has been used for high-temperature oxygen separation, oxygen sensors, and fuel cells [5].

$\mathrm{Zr}$ and $\mathrm{ZrO}_{2}$ films prepared by electron beam evaporation, sputtering, reactive sputtering, pulsed laser deposition, chemical vapour deposition, sol-gel processing, ion beam deposition have been reported $[6,7]$.
Magnetron sputtering is a promising and flexible technique which allows the deposition of films at low temperatures with good properties, but the process is complicated and has not been analysed comprehensively. The reactive magnetron sputtering has a rather broad application for the synthesis of the films of chemical compounds. It has, however, several shortcomings, such as low film deposition rate and the hysteresis effect [8].

It will be observed that the temperature of magnetron target ("cold" and "hot" target) has an influence on the physical processes and the structure of the film formation. Therefore, the purpose of this paper was to analyse the influence of the temperature of the zirconium target on the process of reactive magnetron sputtering, to produce $\mathrm{Zr}$ and $\mathrm{ZrO}_{2}$ thin films by magnetron sputtering in the $\mathrm{Ar}-\mathrm{O}_{2}$ medium, and to analyse them (XRD).

\section{Experimental procedure}

The reactive magnetron deposition method is based on the standard technique, which has been upgraded by applying to it two different cooling systems of mag- 

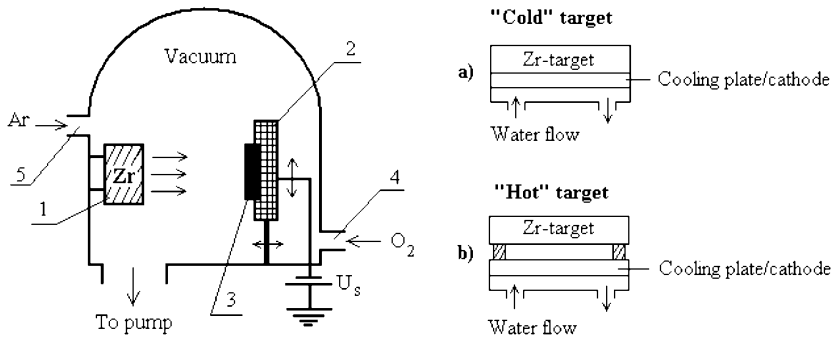

Fig. 1. The experimental scheme: (1) magnetron $\mathrm{Zr}$ cathode, (2) substrate holder with heater, (3) substrate, $(4,5)$ gas inlets; (a) magnetron with "cold" $\mathrm{Zr}$ target, (b) magnetron with "hot" $\mathrm{Zr}$ target.

Table 1. The experimental conditions and process parameters.

\begin{tabular}{lc}
\hline \multicolumn{1}{c}{ Experimental conditions } & Parameters \\
\hline Diameter of $\mathrm{Zr}$ cathode, cm & 15 \\
Discharge voltage of $\mathrm{Zr}$ magnetron, $\mathrm{V}$ & $350-600$ \\
Discharge current of $\mathrm{Zr}$ magnetron, A & $0.5-6$ \\
Distance from $\mathrm{Zr}$ cathode to substrate, cm & $5-10$ \\
Substrate & $\mathrm{Si}(111)$ \\
Primary pressure, Pa & $8 \cdot 10^{-3}$ \\
Partial pressure of oxygen in chamber, $\mathrm{Pa}$ & $0-0.07$ \\
Pressure during deposition (total pressure), $\mathrm{Pa}$ & 0.2 \\
\hline
\end{tabular}

netron target. The principal experimental scheme is shown in Fig. 1. The magnetron target used was a pure $\mathrm{Zr}$ disc, $15 \mathrm{~cm}$ in diameter. A substrate holder with a heater $\left(20-400^{\circ} \mathrm{C}\right)$ was additionally fitted in the vacuum chamber, as well as two inlets of argon and oxygen gas. Indeed, the position of the holder can be regulated by moving it closer to or further from the magnetron cathode as well as by changing its position from vertical to horizontal. Figure 1 shows two different magnetron constructions: (a) when the magnetron $\mathrm{Zr}$ target is cooled with water flow ("cold" target), and (b) when the magnetron $\mathrm{Zr}$ target is thermally isolated from the magnetron cathode ("hot" target). The transcalent glue was present between the "cold" Zr target and the cooling plate. The temperature was measured with a thermopore. The basic parameters of magnetron sputtering can be found in Table 1 .

Deposition rates were measured by weighing substrates before and after deposition with $0.05 \mu \mathrm{g}$ precision. The microstructure of the films was studied by X-ray diffraction (XRD) using the standard BraggBrentano geometry and $\lambda_{\mathrm{Cu}}=0.15405 \mathrm{~nm}$ radiation. The crystallite size and microstrains were calculated using the program WINFIT.

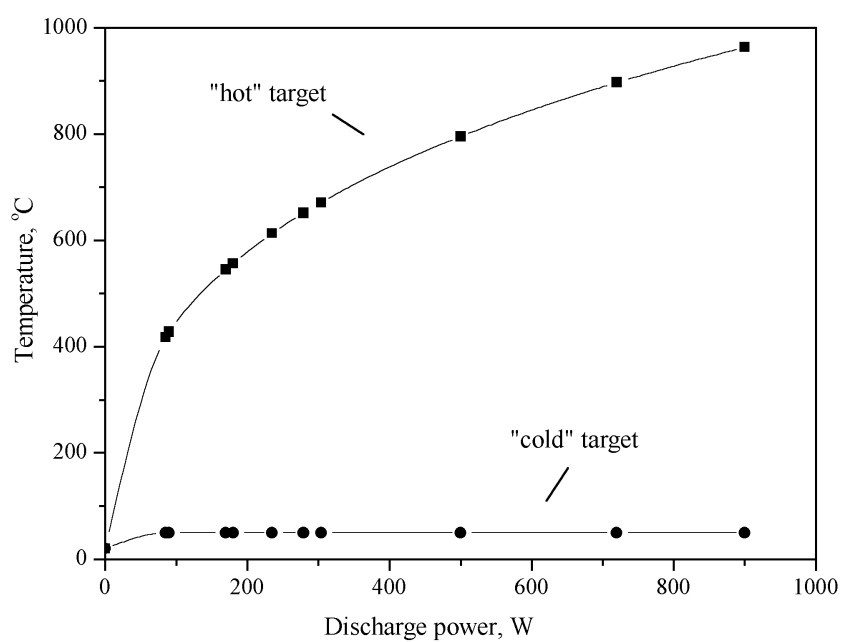

Fig. 2. The dependence of temperature of "cold" and "hot" targets on discharge power.

\section{Results and discussion}

\subsection{The influence of temperature}

The films were deposited by reactive magnetron sputtering when the magnetron $\mathrm{Zr}$ target was cooled with water flow ("cold" target) not in a common way, but being thermally isolated from the magnetron cathode ("hot" target). The temperatures of these targets were significantly different during deposition. The temperature of the "cold" target was almost independent of the discharge power and increased not above $50{ }^{\circ} \mathrm{C}$. The temperature of the "hot" target depended on the discharge power and increased from room temperature to $1000^{\circ} \mathrm{C}$ when the discharge power changed from 0 to $1000 \mathrm{~W}$ (Fig. 2). The dependence of the target temperature on power is delineated by the StephanBoltzmann law, where $95 \%$ of the power are used for heating of the target:

$$
0.95 \cdot N=\alpha \cdot \sigma\left(T^{4}-T_{0}^{4}\right),
$$

where $N$ is the discharge power, $\sigma$ is the StephanBoltzmann constant, $\alpha$ is emissivity for the target material ( $\mathrm{Zr}, \alpha=0.32$ [9]), $T$ is the target temperature, $T_{0}$ is the atmosphere temperature.

One of the characteristics of the reactive magnetron sputtering is hysteresis. The current-voltage characteristics $U=f(I)$ when oxygen flow is constant are shown in Fig. 3. Such dependences indicate that the status of the $\mathrm{Zr}$ cathode target, which determines secondary emission of electrons, is changing. Secondary emission of electrons determines the discharge voltage, i. e. resistance. The measurements are shown only in one way. But given the "cold" and the "hot" tar- 


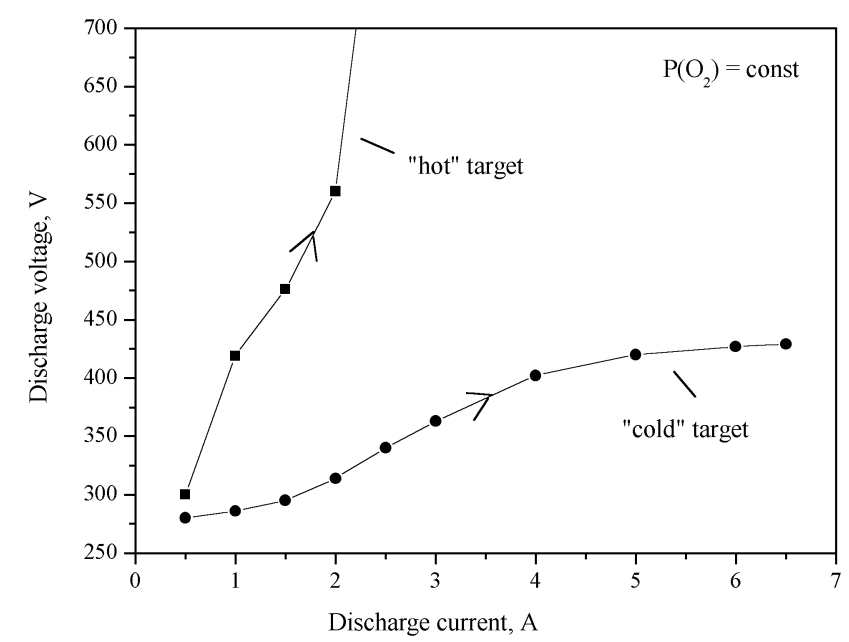

Fig. 3. Current-voltage characteristics when relative oxygen flow is constant (oxygen partial pressure $p_{\mathrm{O}_{2}}=0.04 \mathrm{~Pa}$ ) for "cold" and "hot" Zr metal target.

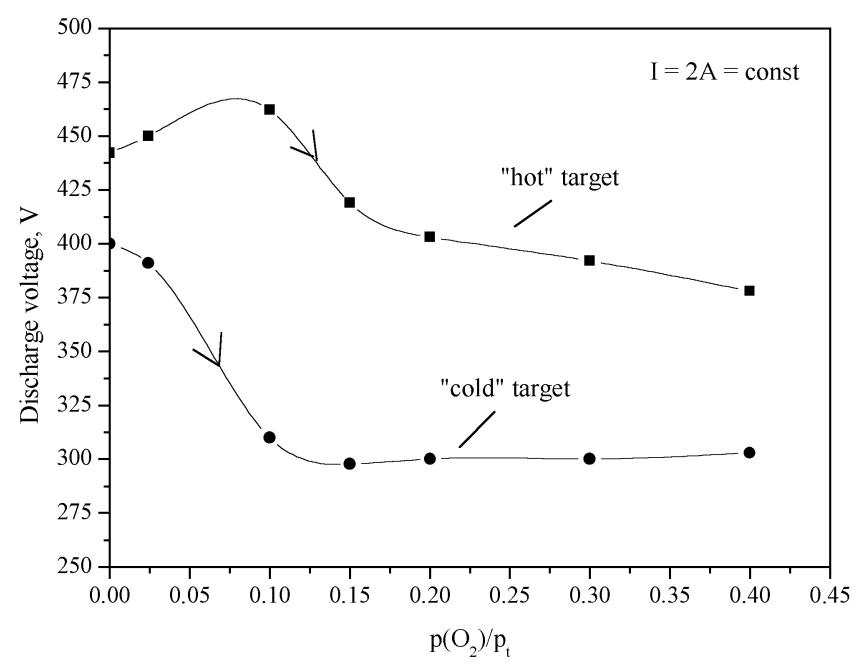

Fig. 4. The dependence of discharge voltage on the ratio of partial pressure of oxygen to total pressure $p_{\mathrm{O}_{2}} / p_{\mathrm{t}}$ for "cold" and "hot"

$\mathrm{Zr}$ metal target when discharge current is constant, $I=2 \mathrm{~A}$.

get, these dependences are radically different. With the "cold" target, when the current increases from 0.5 to 7 A (Fig. 3), at $F\left(\mathrm{O}_{2}\right)=$ const, the voltage increases monotonously and becomes stable at 4 A. Given the "hot" target, when the current increases from 0.5 to 3.2 A (Fig. 3), at $F\left(\mathrm{O}_{2}\right)=$ const, the voltage increases suddenly and does not turn stable.

The dependence of the magnetron cathode voltage on the partial pressure of oxygen for the "cold" and "hot" Zr metal target has also been studied. The dependences of the magnetron discharge voltage on the ratio of the partial pressure of oxygen to the total pressure at constant current of discharge for the "cold" and "hot" Zr target are shown in Fig. 4. With the increase

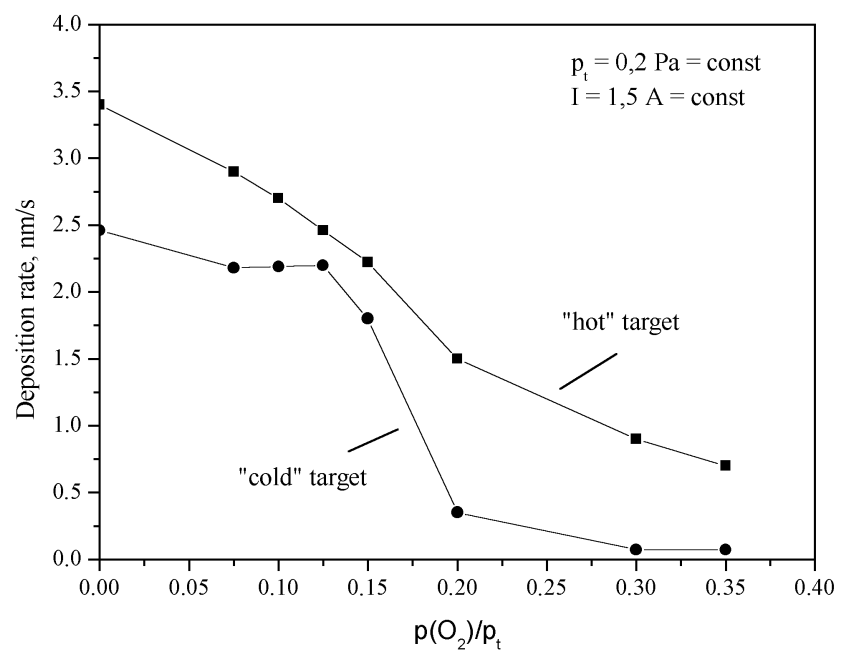

Fig. 5. The dependence of deposition rates of $\mathrm{ZrO}_{2}$ films on the ratio of partial pressure of oxygen to total pressure $p_{\mathrm{O}_{2}} / p_{\mathrm{t}}$ for the $\mathrm{Zr}$ metal target when the $\mathrm{Zr}$ target is "cold" and "hot."

of the partial pressure of oxygen up to $p_{\mathrm{O}_{2}}=0.02 \mathrm{~Pa}$ (ratio of partial pressure of oxygen to total pressure $\left.p_{\mathrm{O}_{2}} / p_{\mathrm{t}}=0.01\right)$ for the "cold" target (discharge current $I=2 \mathrm{~A}$ ) a sudden decrease from 400 to $300 \mathrm{~V}$ in discharge voltage has been observed. When the magnetron target has not been cooled in a common way but has been thermally isolated from the magnetron cathode during the magnetron discharge, the temperature increases up to $600-1000{ }^{\circ} \mathrm{C}$. With the "hot" target (Fig. 4), when increasing $p_{\mathrm{O}_{2}} / p_{\mathrm{t}}$ from 0 to 0.1 , the discharge voltage slowly increases from 450 to $470 \mathrm{~V}$. When increasing $p_{\mathrm{O}_{2}} / p_{\mathrm{t}}$ from 0.1 to 0.4 , the discharge voltage begins to decrease gradually down to $380 \mathrm{~V}$.

\subsection{Synthesis of $\mathrm{ZrO}_{2}$ films}

$\mathrm{ZrO}_{2}$ thin films were deposited by reactive magnetron sputtering, when the $\mathrm{Zr}$ target was "cold" and "hot" in the $\mathrm{Ar}-\mathrm{O}_{2}$ medium $\left(p_{\mathrm{Ar}}=0.2 \mathrm{~Pa}\right.$ ) on Si substrates, at oxygen partial pressure $p_{\mathrm{O}_{2}}=0.04 \mathrm{~Pa}$ and discharge current $I=1.5$ A. Figure 5 demonstrates the change of the deposition rate due to the reactive oxygen flow at different temperatures of the $\mathrm{Zr}$ target. When the $\mathrm{Zr}$ target is "cold," up to $p_{\mathrm{O}_{2}} / p_{\mathrm{t}}=0.125$ the deposition rate slightly decreases from 2.5 to $2.3 \mathrm{~nm} / \mathrm{s}$, and then starts to decline. When the target is clean and the oxygen flow is low, oxygen is inserted in the growing layer, which results in the increase of the deposition rate. The rate of ionic sputtering in this area is much higher than the rate of oxygen absorption on the target. When $p_{\mathrm{O}_{2}} / p_{\mathrm{t}}$ increases, the cathode is fully covered with oxygen, which causes significant decrease of 


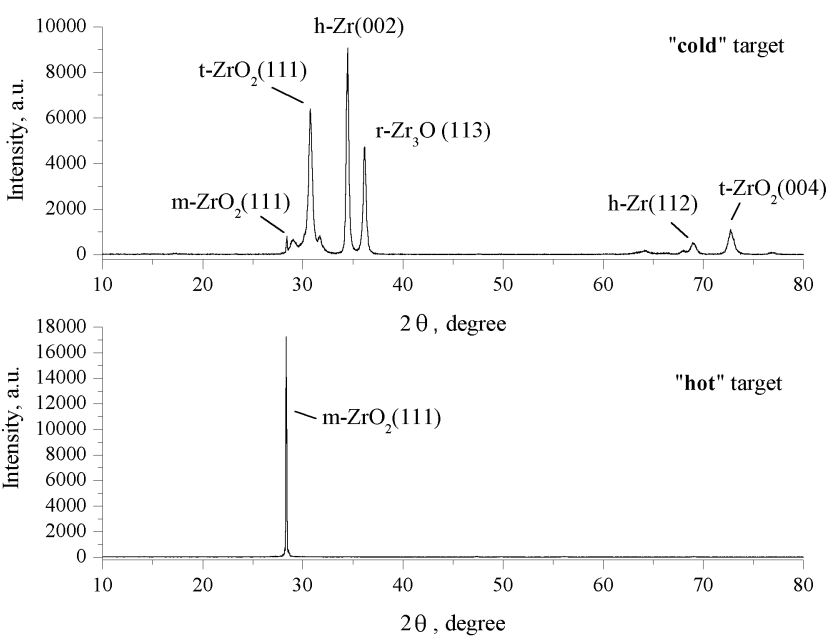

Fig. 6. The XRD diffraction patterns of $\mathrm{ZrO}_{2}$ thin films produced on $\mathrm{Si}(111)$ substrates by reactive magnetron sputtering ( $I=1.5 \mathrm{~A}$, $p_{\mathrm{O}_{2}}=0.04 \mathrm{~Pa}$ ), when the $\mathrm{Zr}$ target is "cold" and "hot."

its ionic sputtering and, ultimately, the deposition rate. When $p_{\mathrm{O}_{2}} / p_{\mathrm{t}}$ of $0.25-0.35$ is achieved, the deposition rate is very low $(0.15 \mathrm{~nm} / \mathrm{s})$ and depends only slightly on the oxygen flow.

When the Zr target is "hot," the deposition rate tends to decrease monotonously with the increased reactive oxygen flow. With the increase of partial pressure of oxygen up to $p_{\mathrm{O}_{2}}=0.07 \mathrm{~Pa}\left(p_{\mathrm{O}_{2}} / p_{\mathrm{t}}=0.35\right)$, the decrease from 3.4 to $0.7 \mathrm{~nm} / \mathrm{s}$ in the deposition rate has been observed.

When $\mathrm{Zr}$ is deposited in pure argon under the same conditions and when the $\mathrm{Zr}$ target is "cold," the deposition rate is 1.4 times lower than it is when the $\mathrm{Zr}$ target is "hot." And when $\mathrm{Zr}$ is deposited in pure oxygen, the deposition rate is even $\sim 4$ times lower (Fig. 5). It may be assumed that in the case of the "hot" target, the phenomenon of physical absorption of the gas has little impact on the discharge process due to the increase in thermal desorption rate.

The X-ray diffraction patterns of $\mathrm{ZrO}_{2}$ films deposited on the $\mathrm{Si}(111)$ substrate are shown in Fig. 6. Figure 6 shows two XRD diffraction patterns, when the $\mathrm{Zr}$ target was "cold" during deposition and when the $\mathrm{Zr}$ target was "hot" during deposition. The parameters of deposition were as follows: partial oxygen pressure $p_{\mathrm{O}_{2}}=0.04 \mathrm{~Pa}$, discharge current $I=1.5 \mathrm{~A}$.

The XRD diffraction pattern when the $\mathrm{Zr}$ target is "cold" demonstrates that under this condition $\mathrm{ZrO}_{2}$ is not completely formed. Many peaks are found in this XRD pattern. One can find pure $\mathrm{Zr}$ and $\mathrm{Zr}_{3} \mathrm{O} . \mathrm{ZrO}_{2}$ has two modifications: monoclinic with texture (111) and tetragonal with textures (111) and (004). The intensity of peaks of the tetragonal phase is considerably
Table 2. Crystallite size of the $\mathrm{ZrO}_{2}$ thin films deposited by reactive magnetron sputtering.

\begin{tabular}{ccc}
\hline $\begin{array}{c}\text { Condition of } \\
\text { Zr target }\end{array}$ & $\begin{array}{c}\text { Crystallographic } \\
\text { orientation }(h k l)\end{array}$ & $\begin{array}{c}\text { Crystallite } \\
\text { size } D, \mathrm{~nm}\end{array}$ \\
\hline "cold" & $\mathrm{h}-\mathrm{ZrO}_{2}(002)$ & 29 \\
& $\mathrm{t}-\mathrm{ZrO}_{2}(111)$ & 19 \\
& $\mathrm{t}-\mathrm{ZrO}_{2}(004)$ & 16 \\
"hot" & $\mathrm{m}-\mathrm{ZrO}_{2}(111)$ & 108 \\
$\mathrm{~m}-\mathrm{ZrO}_{2}(111)$ & 125 \\
\hline
\end{tabular}

higher than in the monoclinic phase. The tetragonal phase of $\mathrm{ZrO}_{2}\left(2 \theta=30.78^{\circ}, 72.72^{\circ}\right)$ and the hexagonal phase of pure $\mathrm{Zr}\left(2 \theta=34.50^{\circ}\right)$ dominate. The XRD diffraction pattern when the $\mathrm{Zr}$ target is "hot" and under the same conditions demonstrates that $\mathrm{ZrO}_{2}$ is completely formed and has only one monoclinic phase $\left(2 \theta=28.36^{\circ}\right)$. Crystallites are oriented in the (111) direction.

The size of the $\mathrm{ZrO}_{2}$ crystallites when the $\mathrm{Zr}$ target was "cold" and "hot" was determined using the Bragg relation. In Table 2, the crystallite size for the $\mathrm{ZrO}_{2}$ thin films is given as a function of crystallographic orientation $(h k l)$. The size of the $\mathrm{ZrO}_{2}$ crystallites when the Zr target was "cold" was significantly smaller $(\sim 16-30 \mathrm{~nm})$ than when the $\mathrm{Zr}$ target was "hot" $(\sim 125 \mathrm{~nm})$.

\subsection{Discussion of the results}

The experiments show that the temperature of the magnetron target during reactive deposition makes influence on numerous characteristics of this process: $U=f(I)$, when $p_{\mathrm{O}_{2}} / p_{\mathrm{t}}=$ const, $U=f\left(p_{\mathrm{O}_{2}} / p_{\mathrm{t}}\right)$ and $v=f\left(p_{\mathrm{O}_{2}} / p_{\mathrm{t}}\right)$, when $I=$ const, where $U$ is the discharge voltage, $I$ is the discharge current, $p_{\mathrm{O}_{2}}$ is the partial pressure of the oxygen gas, $p_{\mathrm{t}}$ is the total pressure, $v$ is the deposition rate. The dependences $U=f(I)$ and $U=f\left(p_{\mathrm{O}_{2}} / p_{\mathrm{t}}\right)$, when the target is "cold" and "hot," show that the resistance of magnetron discharge $R_{\mathrm{d}}=U / I$ depends on the target temperature. Given the increment of temperature, the discharge resistance is higher than usual. This shows that the increase of temperature during the discharge has decreased the rate of plasma ionization. Such a sink in the rate of plasma ionization can be explained: when the ions start to bombard the target, the emission of electrons from the target becomes decreased as well as the number of electrons which are involved in the process of impact ionization. The number of electrons which have generated the ionization of gas 
during DC-glow discharge, is expressed [10] as follows:

$$
n=\frac{n_{0} \mathrm{e}^{\alpha d}}{1-\gamma\left(\mathrm{e}^{\alpha d}-1\right)},
$$

where $n_{0}$ is the primary number of electrons, $\alpha$ is the coefficient of volumetric ionization, $d$ is the distance of ionization, $\gamma$ is the average secondary electron emission coefficient for the entire target surface. Admittedly, $\gamma$ depends on the coverage $\Theta$, when gas is adsorbed on the target [11].

The deposition rate of films $v=v_{\mathrm{m}} / \rho$ is

$$
v_{\mathrm{m}}=\alpha_{\mathrm{m}} \cdot F_{\mathrm{m}} \cdot m_{\mathrm{m}}+\alpha_{\mathrm{i}} \cdot F_{\mathrm{i}} \cdot m_{\mathrm{i}},
$$

where $v_{\mathrm{m}}$ is the deposition rate for the unit of mass, $\rho$ is the density of the material layer, $\alpha_{\mathrm{m}}$ and $\alpha_{\mathrm{i}}$ are the coefficients of metal and oxygen condensation, $F_{\mathrm{m}}$ and $F_{\mathrm{i}}$ are densities of metal and oxygen flows which touch the substrate, $m_{\mathrm{m}}$ and $m_{\mathrm{i}}$ are masses of metal and oxygen atoms (here $m=M / N_{\mathrm{A}}$, where $M$ is the molecular mass and $N_{\mathrm{A}}$ is the Avogadro's number). In view of $M_{\mathrm{Zr}} \gg M_{\mathrm{O}_{2}}\left(M_{\mathrm{Zr}}=91.22, M_{\mathrm{O}_{2}}=15.99\right)$, the deposition rate will depend on the condensation rate of metal atoms and

$$
v_{\mathrm{m}} \approx \alpha_{\mathrm{m}} \cdot F_{\mathrm{m}} \cdot m_{\mathrm{m}} .
$$

Generally, the coefficient of metal condensation $\alpha_{\mathrm{m}}=1$, therefore,

$$
v_{\mathrm{m}} \approx F_{\mathrm{m}} \cdot m_{\mathrm{m}} .
$$

Consequently, aiming to measure the deposition rate, the dependence $F_{\mathrm{m}}$ on the parameters of magnetron discharge process must be found. $F_{\mathrm{m}}$ depends on the coverage $\Theta$ of the target, on the sputter yield $Y_{\mathrm{m}}$, and the flow of ions which bombard the target, $I /[(1+\gamma) e] . v_{\mathrm{m}}$ is equal to

$$
v_{\mathrm{m}} \approx K Y_{\mathrm{m}}(1-\Theta) \frac{I}{(1+\gamma) e},
$$

where $K$ is the factor of geometry, $e$ is the electron charge. Therefore, the deposition rate also depends on the coverage $\Theta$ of the target.

If we presuppose that only physical monolayer adsorption takes place on the target, then $\Theta$ can be found from the equality

$$
\begin{gathered}
\alpha(1-\Theta) F_{\mathrm{O}_{2}}+\varepsilon(1-\Theta) f\left(\frac{p_{\mathrm{O}_{2}}}{p_{\mathrm{t}}}\right) \frac{I}{(1+\gamma) e} \\
=Y_{\mathrm{O}_{2}} \Theta \frac{I}{(1+\gamma) e}+\Theta k_{0} \mathrm{e}^{-E /(k T)} .
\end{gathered}
$$

The left side of the equality specifies the adsorption rate of oxygen, whereas the right side indicates the desorption rate. In Eq. (6), $F_{\mathrm{O}_{2}}=p_{\mathrm{O}_{2}} /\left(2 \pi m_{\mathrm{O}_{2}} k T\right)^{1 / 2}$, $f\left(p_{\mathrm{O}_{2}} / p_{\mathrm{t}}\right)$, the fraction of positive ions that are reactive gas species in the discharge current, is shown. Here $\alpha$ is the sticking coefficient for neutral reactive gas molecules on the target surface, $\varepsilon$ is the the sticking coefficient for reactive gas ionic species impinging on the target surface, $Y_{\mathrm{O}_{2}}$ is the average sputtering yield of oxygen gas molecules, $k_{0}$ is a constant. The term $\Theta k_{0} \mathrm{e}^{-E /(k T)}$ specifies the thermal desorption rate, the exponential of which depends on the temperature of the target $T$ and desorption activation energy $E$. It is apparent from Eq. (6) that

$$
\begin{aligned}
& \Theta= \\
& \frac{\alpha F_{\mathrm{O}_{2}}+\varepsilon f\left(\frac{p_{\mathrm{O}_{2}}}{p_{\mathrm{t}}}\right) \frac{I}{(1+\gamma) e}}{\frac{I}{(1+\gamma) e}\left[Y_{\mathrm{O}_{2}}+\varepsilon f\left(\frac{p_{\mathrm{O}_{2}}}{p_{\mathrm{t}}}\right)\right]+\left(k_{0} \mathrm{e}^{-E /(k T)}+\alpha F_{\mathrm{O}_{2}}\right)} .
\end{aligned}
$$

The above formula (7) indicates that the target coverage $\Theta$ as well as the temperature of the target can radically influence the discharge resistance and deposition rate. This is equally supported by the results of our experiments.

It is important to note that during the reactive magnetron deposition, when the target is "hot," one can obtain a lower coverage $\Theta$ with molecules of active gas than the coverage $\Theta$ of the growing layer, the temperature of which is lower. The realization of such conditions enable one to form layers of chemical compounds with high deposition rates. When the target is "cold" and "hot," the microstructure of the formative layers changes. When the target is "hot," the layers of chemical compounds are formed on the substrate from the atoms of metal received from the ion dust (higher kinetic energy) and molecules of active gas, which touch the target in the gas phase. When the target is "cold," the layers of chemical compounds are formed on the substrate from the atoms of metal and oxygen (higher kinetic energy), which bombard the outside of the target.

\section{Conclusions}

This study has demonstrated that the temperature of the $\mathrm{Zr}$ target does influence the process of reactive magnetron deposition. When the magnetron $\mathrm{Zr}$ target was thermally isolated from the magnetron cathode, the thermal desorption process was enabled increasing the deposition rate of $\mathrm{ZrO}_{2}$ after the increase of the amount 
of pure oxygen by about 4 times. The structural properties of $\mathrm{ZrO}_{2}$ are changing, too. When the $\mathrm{Zr}$ target is "hot" during deposition, $\mathrm{ZrO}_{2}$ with $p_{\mathrm{O}_{2}}=0.04 \mathrm{~Pa}$ is completely formed and has only one monoclinic phase $\left(2 \theta=28.36^{\circ}\right)$. The crystallites are $\sim 120 \mathrm{~nm}$ in size and oriented in the (111) direction.

\section{References}

[1] S. Collard, H. Kupfer, W. Hoyer, and G. Hecht, Growth of nitrogen stabilised cubic $\mathrm{ZrO}_{2}$ phase by reactive magnetron sputtering using two reactive gases, Vacuum 55, 153-157 (1999).

[2] P. Baumeister and O. Arnon, Use of hafnium dioxide in multilayer dielectric reflector for the near UV, Appl. Opt. 16, 439-444 (1977).

[3] S.M. Meier and D.K. Gupta, J. Eng. Gas Turbines Power, Trans. ASME 116, 250 (1994).

[4] S.J. Wang, C.K. Ong, S.Y. Xu, and P. Chen, Crystalline zirconia oxide on silicon as alternative gate dielectrics, Appl. Phys. Lett. 78(11), 1604-1607 (2001).
[5] J. Will, A. Mitterdorfer, C. Kleinlogel, and D. Perednis, Fabrication of thin electrolytes for second-generation solid oxide fuel cells, Solid State Ionics 131, 79-96 (2000).

[6] M. Boulouz, A. Boulouz, A. Giani, and A. Boyer, Influence of substrate temperature and target composition on the properties of yttria-stabilised zirconia thin films grown by reactive magnetron sputtering, Thin Solid Films 323, 85-92 (1998).

[7] M. Žadvydas, S. Tamulevičius, and K. Šlapikas, Application of plasma sputtering, in: Modern Materials and Technologies, Materials of the Republican Conference (Palanga, 2002) p. 52 [in Lithuanian].

[8] R.E. Hummer and K.H. Günther, Thin Films for Optical Coatings (CRC Press, 1995).

[9] A. Guinier, R. Jullien, and W.J. Dreffin, The Solid State, From Superconductors to Superalloys (Oxford University Press, 1989) p. 280.

[10] E.G. Kalashnikov, Electricity (Moscow, 1977) p. 589 [in Russian].

[11] E.W. Daniel, Collision Phenomena in Ionized Gases (Willey, New York/London/Sydney, 1964) p. 832.

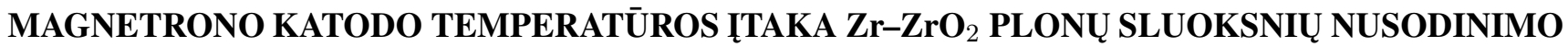 SPARTAI IR JU SANDARAI
}

\author{
J. Čyvienè, M. Laurikaitis, J. Dudonis
}

Kauno technologijos universitetas, Kaunas, Lietuva

\section{Santrauka}

Tirtas reaktyvinis magnetroninis nusodinimas, esant ivvairiai Zr katodo temperatūrai. Katodo temperatūra buvo keičiama nusodinant sluoksnius magnetronu, kurio katodas buvo tiesiogiai šaldomas vandeniu (“šaltas” katodas), arba naudojant šilumiškai izoliuotą katodą ("karštas" katodas). Pirmuoju atveju taikinio temperatūra siekè $30-50{ }^{\circ} \mathrm{C}$, antru $-900-980{ }^{\circ} \mathrm{C}$. Buvo išmatuotos magnetrono katodo $(\mathrm{Zr})$ voltamperinès priklausomybès esant "šal- tam" ir "karštam" katodui, kai deguonies dalinis slègis pastovus, magnetrono katodo įtampos priklausomybès nuo deguonies dalinio slègio, kai išlydžio srovès stipris pastovus, bei sluoksnių nusodinimo spartos priklausomybè nuo dalinio deguonies slègio. Ištyrus magnetrono katodo temperatūros įtaką reaktyviniam nusodinimui, $\mathrm{ZrO}_{2}$ ploni sluoksniai buvo nusodinti ant $\mathrm{Si}(111)$ padèklų. Sluoksnių sandaros buvo ištirtos, remiantis Röntgen'o difrakcine analize. 